\title{
The Significance of the Junior College Library in the Educational Program
}

Dean Moe of Virginia Junior College, Virginia, Minn., read this paper at the meeting of the Junior College Libraries Section of the A.C.R.L., June 25, 1942.

$\mathrm{T}$ HE JUNIOR COLLEGE LIBRARY is just beginning to get the recognition which it deserves. Most junior colleges are the outgrowth of secondary education, and it is only natural that they have inherited the weaknesses as well as the virtues of secondary education. By and large, I am sure that one of the outstanding failures of secondary education even today is the lack of provision for the encouragement of selfdirected habits of study through adequate library service.

The junior college, like any other member of the educational family, has particularized functions. Important as it is in high school, self-propelled intellectual activity becomes a compelling objective on the junior college level. This fact makes the library a vital part of any junior college organization.

It has been stated that the library is the power plant of an educational institution. It is not merely a department, a single spoke in the educational wheel; it is more than that. Its influence transcends all departments. It is the hub of the instructional wheel. Because of the type of work the junior college is designed to do, the library plays just as significant a role in the success of this institution as it does in a four-year college or university. The chief yardstick of appraisal of any junior college organization is the quality of its library service. In the language of investment circles, this is the acid test.

During the past several years, I have had the privilege of visiting many junior colleges in all sections of the country. In these visits, I have made a special point of spending considerable time in the various libraries. I have inquired about the number and training of librarians, about budgets, general policies, faculty and administrative relationships, student use, and about the facilities for special reading. Further, I have almost always asked to see the shelf of unaccessioned books in order to get some idea of the type of books added currently to the library. I have studied, too, certain departmental collections in fields which I have felt I should know more about than others.

My general observation is that there is widespread recognition of need for improved library service but also that junior college administrations as a rule have not met the library problem with the same firmness and determination with which other problems have been met. This observation applies to some of the betterknown junior colleges, as well as to those 
less well known. In some cases the libraries are conspicuously weak, and in one instance eight or ten copies of Hazen's Europe Since 1815 seemed to be almost the only source of reference reading in modern European history. Frequently what are called libraries are not libraries at all. They are unattractive rooms under the supervision of workers with little understanding of the true function of a junior college organization.

The function of the library in any institution must be interpreted in the terms of the aims and objectives of that institution. Amongst others, one leading objective common to all junior colleges is the rounding out of the cultural implications of secondary education. This is merely another way of saying that one of the chief purposes of the junior college is to provide the facilities for general education.

\section{General Education}

There is much confusion about the meaning and scope of general education. Attempting to define the term is much like trying to reduce the objectives of education into a pattern small enough to be usable and at the same time broad enough to include the divergent views of the many educators-something that is very difficult to do. Still, I think we all have rather definite views regarding the nature of general education. In I93I Owen D. Young made a significant commencement address under the title "The Five Final Questions at Commencement" in which is epitomized, without his meaning to do so, much that has been written since regarding the meaning and scope of general education. Some may wish to follow President Hutchins and Professor Adler; others, Walter Lippmann in his analysis of recent date. In any of these approaches, the final result is much the same.

Personally, I think that Henry M. Wriston has done the best job of all in bringing order out of chaos in this field when he defines the scope of general education in terms of discipline. His statement, it should be observed, antedates many of the current analyses. General education, according to him, combines four basic disciplines-the discipline of precision, the discipline of appreciation, the discipline of hypothesis, and the discipline of reflective synthesis. Indeed, it might well be said that President Wriston practices what he preaches, for the statement of his four disciplines is an excellent synthesis of practically all writing that has been done in the field of general education.

It is quite inconceivable that there could be any considerable attainment in the perfection of these disciplines on the part of freshmen and sophomores without an adequate library program. Precise thinking in the natural sciences can be attained through the laboratory and the textbook, but precise thinking in the broader problems now confronting the world can be attained only by a ready grasp of the implications of these problems to the world. A full understanding of these implications can come only by wide reading and much reflection.

Likewise, the remainder of President Wriston's disciplines all presume wide understanding of the broader fields of knowledge, an understanding which presupposes extensive reading and study.

\section{The Library in General Education}

A program of general education-the common denominator of all junior college functions-is not possible without a vigorous library administration. Adequate and properly trained personnel and ample 
budgets are necessary. These are basic requirements, but they alone will not insure a satisfactory library program. There must be, in addition, an acceptance by junior college administrations of the following principles:

I. The librarian, like all members of the faculty, must have a good understanding of the aims and purposes of junior college education and, more particularly, an appreciation of the particularized functions of the institution in which he works. This understanding can be achieved only by a close working relationship between the librarian and the person charged with the over-all responsibility for the administration of the junior college. It might well be that this close association should even become a consolidation of the two separate offices of librarian and supervisor of instruction, as at Stephens College. Without such complete consolidation, however, the two responsibilities should be as closely coordinated as possible. The library, as I have stated before, is not just another department-it yields a service which undergirds all departments.

2. The librarian must have full authority to coordinate all technical features of the library service. Moreover, I don't believe that full coordination can be achieved on the basis of statistical procedures alone. Budgetary allotments by departments, for example, may be used as a guide in purchasing, but the librarian's judgment must be permitted to modify such allotments if occasion requires. Procedures must be kept flexible, and like all administration, business, government, or military, the quality of the library administration will reflect the views, knowledge, and vision of the man in charge.

The librarian to do his job properly must have responsible authority. But his function is not that of a custodian. Mr. MacLeish draws the distinction between a keeper of physical books and a keeper of intellectual books.

If it is the intellectual book rather than the physical book of which the librarian is keeper, then the profession of the librarian is not and cannot be the neutral, passive, negative profession of the guardian and fiduciary, but must become instead the affirmative and advocating profession of the attorney for a cause. ${ }^{1}$

3. Students in the freshman and sophomore years in college will read in proportion to the extent that they are encouraged and inspired to read. It is the librarian's responsibility to have an intimate knowledge of the reading habits of students in general and of the reading practices of students in various departments.

As the Committee on College and University Teaching of the American Association of University Professors has stated:

The purpose of college teaching is to induce self-propelled intellectual activity on the part of the student. Accordingly, a frank recognition of the principles of selfeducation under guidance will suggest a sufficient definition of good teaching. To teach effectively is to lead, to inspire, and to guide the learner.

A valuable insight into the work of the classroom should be available to the supervisor of instruction by way of the library. Students will read more if they are inspired to read by instructors who are themselves well-read and who are convinced of the value of extensive reading. Furthermore, the librarian can do much to stimulate reading by using the many techniques familiar to us all.

4. The junior college library is not a research library. Its chief purpose is to

\footnotetext{
1 MacLeish, Archibald. Time to Speak. Houghton, I94I, p. 29.
} 
serve the needs of instruction on the freshman and sophomore levels. This does not mean, of course, that the purchase of special books, journals, and documents should not be made, for in serving the needs of instruction it is necessary to provide the faculty with their particular and specialized requirements. Ample provision should be made, too, for the recreational and general reading.

Research in problems related to the learning process and the improvement of the methods of teaching does fall within the competence of the junior college. It is desirable for all junior colleges to expand their library holdings in the field of professional education including educational psychology.

5. Since most students have a practical interest in the problems of the contemporary world and because world changes have occurred at such a rapid pace since 1929, provision should be made in the junior college library budget for the regular purchase of all significant publications of a nontechnical nature as they are published. Extensive exploration in the field of contemporary problems: scientific, social, economic, and international yields a great fascination for most students.

The one compelling problem of the day is the survival of democracy. And junior college students have a greater interest in it, as they should, than in any other problem. If the librarian is to be the advocate of a cause, as Mr. MacLeish affirms he ought to be, he can do much to guide students in their study of this overwhelming subject.

One might say that in the development of a junior college library primary emphasis in the early stages should be upon the rounding out of the recommended collections and that secondary emphasis should be upon books of current information. As the library progresses in size and importance, this emphasis should be reversed, with the understanding, of course, that careful balance should be maintained. The point of perfect balance is a theoretical one and one that is subjectively derived; as such, it must be determined by the judgment of the librarian.

6. Finally, it should be remembered that there is a human side to library administration. Reviewing, purchasing, accessioning, and circulation statistics are all a necessary part of library administration, but they are not all. The library must be a place of charm, of cheer, and warmth. I think that I am correct in saying that many of us, as we reflect upon our student days, are most critical of the cold, impersonal way in which the library administered its service. The mass production methods of a large university library tend to dispel rather than enliven intellectual interest in the undergraduates.

Recent trends in education reveal the need for the "personal point of view" in the classroom and out-and certainly it applies to library relationships. An adequate library service is an individualized service. The more complete it is, the greater aid it will be to the major purpose of the junior college-good instruction. 